\title{
Health Information Seeking Behaviour Among Students in the Federal University of Technology, Akure, Ondo State, Nigeria
}

\author{
Omonigho Angela Israel $^{*} \quad$ Olufemi Olusegun Samuel \\ Federal University of Technology, Akure (FUTA), PMB 704, Akure, Ondo State, Nigeria
}

\begin{abstract}
The study investigated the health information-seeking behaviour of students at the Federal University of Technology, Akure in Nigeria. Information resources exploited by university students to meet health information needs were also examined. The study made use of the descriptive survey design, randomly sampling respondents' opinions on reasons for seeking health information and factors that militate against the effective use of health information. Of 377 respondents, 239 (63.4\%) of them were disposed to seeking information on physical fitness or exercise and cold or flu. Newspaper (283 or $75.1 \%$ ) was identified as respondents' commonest source of health information. For university students, a major inhibitor of health information seeking outside the library is the high cost of accessing health information for personal use (318 or 84.4\%). But within the library, the uncooperative attitude of library personnel ( 240 or $63.7 \%$ ) was identified as respondents' major hindrance in accessing health information in the library. The study recommended adequate provision of health information resources for students' use and regular library personnel training to improve professional skills required for effective dissemination of health information, particularly to university students.
\end{abstract}

Keywords: information, information need, health information, health information-seeking behaviour, university students, library personnel

DOI: $10.7176 / \mathrm{JIEA} / 10-2-03$

Publication date:March $31^{\text {st }} 2020$

\section{Introduction}

In the present dispensation, information is a necessary commodity for daily survival. Out of a myriad of needs that beleaguer humans on a regular basis, the need for relevant, requisite information to meet critical needs is considered topmost priority. Information is crucial to human existence (Ajiboye \& Tella 2007) and must be accorded the importance it deserves to enhance its effective use in all facets of human endeavour.

In health circles, access to information for quality medical care is deemed very important because of its role in improving the quality of man's well-being. Adequate provision and use of health information reduces mortality rate and prolongs the life's span of a nation's citizenry. For people from all walks of life, including health care providers, provision of health information is essential in increasing access to existing health care facilities and facilitating the use of new medical technologies (Andualem, Kebede, \& Kumie 2013). More importantly, health information is considered very essential for youths who make up a substantial part of the world's population. According to Esmaeilzadeh, Ashrafi-rizi, Shahrzadi, \& Mostafavi (2018), a fifth of the world's population is between 10 and 19 years old and $85 \%$ of them live in developing countries. Provision of health information for young people is fundamental to national development. The youth populace is the strength of a nation's tomorrow. Therefore, the security of their wellbeing becomes pertinent if societal growth must be guaranteed.

Health information-seeking among young people especially in tertiary institutions is a growing concern as incidents of high-risk behaviours in young people are on the increase (Esmaeilzadeh et al. 2018). High-risk behaviours involve a display of attitudes that attract undesirable results. They include substance abuse, alcohol consumption, physical inactivity, high fast food intake, and cigarette smoking. Other behaviours that portend risk among youths may include susceptibility to sexual and reproductive problems which they tend to suffer more than adults (Senderowitz, Hansworth, \& Carthy 2003). According to Boltena, Khan, Asamoah, and Agardh (2012), youthful exuberance makes young people more liable to require medical and sexual interventions and the activity of seeking such information may be done independently or through solicited assistance from other people.

For young people in higher institutions, the advent of Information and Communications Technology (ICT) now makes them to proactively seek information on issues of interest including health information. In an investigation into the primary sources of health information by Dutta-Bergman (2004), the internet was revealed as a major source of health information and major seekers of health information via electronic means are adolescents or youths (Onwe \& Okocha 2019; Okoniewski, Lee, Rodriguez, Schnall, \& Low 2015). Also, in Nigeria, the expanding frontiers in internet provision in most universities including The Federal University of Technology, Akure has given rise to the quest for health information among youths.

At the inception of The Federal University of Technology, Akure (FUTA) Nigeria in 1982, only three faculties or schools were established. They were the School of Agriculture and Agricultural Technology (SAAT), the School of Earth and Mineral Science (SEMS), and the School of Pure and Applied Sciences (now known as the School of Science (SOS). In addition to these schools, four more were created which exist to date. They include; 
the School of Engineering and Engineering Technology (SEET), the School of Environmental Technology (SET), the School of Postgraduate Studies (SPGS), and the School of Health and Health Technology (SHHT).

As aforementioned, present-day society is plagued with the surge of drug abuse and unhealthy indulgences that certain cultures including those within tertiary institutions have promoted. Unfortunately, many young people are inundated by them and struggle to live healthily by attempting to access health information which they hope will bring relief or total cure for such health conditions. This emphasises the exigency for the provision of health information which is necessary to ensure the physical, emotional, and mental stability of university students and hence, the need to investigate the health information-seeking behaviour of students in the Federal University of Technology, Akure.

\section{Description of Study}

\subsection{Statement of the Problem}

Information seeking is an age-long activity of humans in their quest for fulfilment. However, the quality of search for health information demands more attention in order to promote physical and mental soundness for present and future generations. For the teeming youth population, this may prove daunting as incidences show young people as potential sufferers of poor health conditions (Boltena et al. 2012). In a study on the health information-seeking behaviour of Nigerian university students, Onwe \& Okocha (2019) reported life expectancy in Nigeria, according to World Health Organization report in 2018, to stand at 55 years. In their opinion, Nigeria has recorded a high mortality rate among youths owing to substance abuse and sexual activities.

Similarly, Esmaeilzadeh et al. (2018) reported the scourge of alcohol and drug abuse and illicit sexual practices among Iranian youths which has caused a decline in the health condition of young people in the country. This awareness has caused youths to seek health information to improve their health status. However, the current state of the provision of health information is brought to the fore. While it is important to create platforms where information-seeking behaviours of youths would be considered (Shi \& Luo 2019; Nwezeh 2008), a question is posed; 'what institution is responsible for the provision of health information?' Esmaeilzadeh et al. (2018) opined that the library among other agencies has a role to play in the provision of health information to young people. If this should be so, how much health information do youths, particularly university students obtain from academic libraries and what other methods do they use to obtain health information to improve on their health conditions? These are questions that this study attempts to answer.

\subsection{Objectives of the Study}

The study has the following objectives:

1. To identify the health information needs of university students

2. To determine the health information resources exploited by university students

3. To find out university students' intentions for seeking health information

4. To investigate the problems experienced by university students when seeking health information in the library.

5. To identify the factors that hamper access to health information among university students.

\subsection{Research Questions}

The following research questions guided the study:

1. What are the health information needs of university students?

2. What information resources do university students exploit to meet their health information needs?

3. What are the intentions for seeking health information among university students?

4. What problems do university students encounter when seeking health information in the library?

5. What are the factors that inhibit access to health information among university students?

\section{Literature Review}

Health information seeking is a salient requisite for healthy living. The attitude of seeking health information is necessary to promote health literacy among university students and to ensure the acquisition of balanced education in tertiary institutions (Onwe \& Okocha 2019). Several investigations on health information-seeking behaviour abound. Onwe \& Okocha's study (2019) reflected common health information needs of students or individuals belonging to the adolescent stage. Respondents mostly sought information on how to keep fit physically (88.2\%). This was closely followed by the need for sexual and reproductive health information $(80.9 \%)$. Which was also emphasised in the study of Boltena et al. (2012) who investigated barriers faced by Ugandan university students in seeking medical care and sexual health counselling. The study registered the existence of gaps in meeting the prevailing sexual health information needs of adolescents. Though youths are cognisant of these practices that lead to high-risk behaviours (Esmaeilzadeh et al. 2018), they are more comfortable seeking information on general body wellness including skincare for improved physical appearance (Ettel, Nathanson, Ettel, Wilson, \& Meola 
2012).

A study on the health information-seeking behaviour of tertiary students by Obasola \& Agunbiade (2016) emphasised youths' need for sexual health information among others including physical and mental fitness. In meeting these needs, the internet is viewed as a common source of health information among youths (Asibey, Agyeman, \& Dankwah 2017) because it provides gateways and links to other sources of information and the apparatus for electronic support groups (Ettel et al. 2012). Though physicians and medical practitioners are recognised authorities in providing authentic health information, youths seldom seek them for medical advice (Ettel et al. 2012). However, they show sufficient confidence in family and friends to seek out information on health-related issues (Esmaeilzadeh et al. 2018) and perceive them to be more reliable sources of health information than the internet (Okoniewski et al. 2015) especially to meet pressing health information needs (Percheski \& Hargital 2011).

The place of the library is critical in the provision of health information. Libraries are custodians of relevant information for individual and societal use and therefore, should possess the quality of dispensing all types of information. In certain climes, the perception of a librarian's function is broadened to include educating and providing health information to students, health care providers, researchers, and the public. This evolution inevitably calls for the review of the curriculum required for the formal training of librarians especially at the postgraduate or professional level (Ma, Stahl, \& Knotts 2018). But the situation as indicated in some studies reflect a lack of promotion of health information by libraries (Onwe \& Okocha 2019; Duhon \& Jameson 2013). Libraries' full potentials are yet to be fully exploited by youths (Okoniewski et al. 2015; Boltena et al. 2012). Availability and accessibility have been identified as major factors influencing youths' search for health information (Boltena et al. 2012). Also, some researchers divulge some problems encountered by youths during their quest for health information. Moreso, the correctness of the information sought is a matter of concern to youths. Though they are positively disposed to the notion of seeking health information, Esmaeilzadeh et al. (2018) opined that youths need every assistance available including such from the library to enable them to access accurate, timely information to meet health information needs which is the rationale behind the investigation into the health information-seeking behaviour among students in the Federal University of Technology, Akure, Ondo State, Nigeria.

\section{Methodology}

The descriptive survey design was adopted for the study. The target population for the research comprised students of all levels in the Federal University of Technology, Akure.

\subsection{Sampling Size and Sampling Technique}

A sample size of 377 was used for the study. The use of this sample size is intended to attain generalised knowledge about the whole population. Contained in a formula devised by the research division of the National Education Association, Krejcie \& Morgan (1970) stated a means of determining the sample size of any given population (see Appendix 2). In the table, no calculation is required for its use. When using the formula, the increase in size is proportionate to the increase in the population, though in a diminishing rate, and remains relatively constant at slightly more than 380 cases (Krejcie \& Morgan 1970).

\subsection{Data Collection Instrument}

A questionnaire was used to elicit responses from all participants in the study. The questionnaire comprised twelve (12) questions which included queries on respondents' background, variant information needs and resources they consulted when seeking health information. Information on challenges encountered during the use of health information and the library's role in the provision of health information to respondents were also sought.

\subsection{Data Collection Method}

Questionnaire distribution and collection spanned six (6) weeks. In order to get sufficient coverage, students were engaged to fill the questionnaires after lecture periods and during reading hours in the university's main library and in the school or faculty libraries. At some instances, permission was sought from lecturers to allow students to fill out the questionnaires during lecture periods.

\subsection{Data Analysis}

The questionnaires returned were sorted and verified to ensure proper usability. The questionnaires were electronically processed to facilitate analysis. The data collected was organised via descriptive statistical methods and its analysis was facilitated by the use of Statistical Package for Social Sciences (SPSS).

\section{Results}

Data obtained from the study centred on the health information-seeking behaviour of students of the Federal University of Technology Akure, Ondo State, Nigeria. The study examined the health information needs of 
respondents; types of health information sought as well as information sources exploited to meet the needs. Respondents' perception of the library's role in the provision of health information was also sought to determine the level of their use of the library and its resources within the University.

Table 1. Faculty of Respondents

\begin{tabular}{|l|l|l|}
\hline Name of School/Faculty & Frequency & Percentage (\%) \\
\hline School of Agriculture and Agricultural Technology & 59 & 15.6 \\
\hline School of Computing & 23 & 6.1 \\
\hline School of Earth and Mineral Sciences & 47 & 12.5 \\
\hline School of Engineering and Engineering Technology & 69 & 18.3 \\
\hline School of Environmental Technology & 98 & 26.0 \\
\hline School of Health and Health Technology & 24 & 6.4 \\
\hline School of Management Technology & 27 & 7.2 \\
\hline School of Sciences & 30 & 8.0 \\
\hline Total & $\mathbf{3 7 7}$ & $\mathbf{1 0 0 . 0}$ \\
\hline
\end{tabular}

Table 1 shows the number of students that participated from eight (8) schools or faculties in the Federal University of Technology, Akure, Ondo State, Nigeria. From the table, 98 (26.0\%) participants were from the School of Environmental Technology. This was closely followed by students from the School of Engineering and Engineering Technology (69 or 18.3\%). 59 (15.6\%) respondents were students in the School of Agriculture and Agricultural Technology, 47 (12.5\%) were from the School of Earth and Mineral Sciences, and $30(8.0 \%)$ were students from the School of Sciences. Schools with a low number of respondents included: The School of Management Technology (27 or 7.2\%), the School of Health and Health Technology (24 or 6.4\%), and School of Computing (23or 6.1\%). Findings showed that students from the School of Environmental Technology participated the most in the study.

Table 2. Departments of Respondents

\begin{tabular}{|l|l|l|}
\hline Department & Frequency & Percentage (\%) \\
\hline Agric. Extension \& Communication Tech & 10 & 2.7 \\
\hline Agric. \& Resource Economics & 6 & 1.6 \\
\hline Animal Prod. \& Health & 9 & 2.4 \\
\hline Crop, Soil \& Pest Management & 4 & 1.1 \\
\hline Ecotourism \& Wildlife Management & 4 & 1.1 \\
\hline Fisheries \& Aquaculture Tech & 3 & 0.8 \\
\hline Forestry \& Wood Technology & 17 & 4.5 \\
\hline Food Science \& Technology & 10 & 2.7 \\
\hline Computer Science & 8 & 2.1 \\
\hline Cyber-Security & 4 & 1.1 \\
\hline Information Science & 2 & 0.5 \\
\hline Information Technology & 6 & 1.6 \\
\hline Software Engineering & 4 & 1.1 \\
\hline Applied Geophysics & 9 & 2.4 \\
\hline Applied Geology & 2 & 0.5 \\
\hline Marine Science \& Technology & 3 & 0.8 \\
\hline Meteorology and Climate Science & 4 & 1.1 \\
\hline Remote Sensing \& Informatics & 4 & 1.1 \\
\hline Agricultural \& Environmental Engineering & 4 & 1.1 \\
\hline Civil \& Environmental Engineering & 6 & 1.6 \\
\hline Electrical \& Electronics Engineering/CPE & 10 & 2.7 \\
\hline Mechanical Engineering & 12 & 3.2 \\
\hline Met. \& Material Engineering & 15 & 4.0 \\
\hline & & \\
\hline
\end{tabular}




\begin{tabular}{|l|l|l|}
\hline Department & Frequency & Percentage (\%) \\
\hline Mining Engineering & 15 & 4.0 \\
\hline Production and Industrial Engineering & 10 & 2.7 \\
\hline Architecture & 29 & 7.7 \\
\hline Building & 25 & 6.6 \\
\hline Estate Management & 14 & 3.7 \\
\hline Industrial Design & 9 & 2.4 \\
\hline Quantity Survey & 12 & 3.2 \\
\hline Surveying and Geo-Informatics & 7 & 1.9 \\
\hline Urban \& Regional Planning & 22 & 5.8 \\
\hline Biomedical Technology & 5 & 1.3 \\
\hline Human Anatomy & 5 & 1.3 \\
\hline Physiology & 3 & 0.8 \\
\hline Accounting & 3 & 0.8 \\
\hline Business Administration & 18 & 4.8 \\
\hline Economics & 3 & 0.8 \\
\hline Entrepreneurial Management Technology & 4 & 1.1 \\
\hline Project Management Technology & 3 & 0.8 \\
\hline Transport Management Technology & 3 & 0.8 \\
\hline Biochemistry & 11 & 2.9 \\
\hline Biology & 4 & 1.1 \\
\hline Chemistry & 4 & 1.1 \\
\hline Mathematical Science & 4 & 1.1 \\
\hline Microbiology/Biotechnology & 3 & 0.8 \\
\hline Physics & 2 & 0.5 \\
\hline Statistics & 3 & 0.8 \\
\hline TOTAL & $\mathbf{3 7 7}$ & $\mathbf{1 0 0 . 0}$ \\
\hline
\end{tabular}

Table 2 highlights the departments of students that participated in the study. A total of 48 departments were represented in the study reflecting the department of Architecture (29 or 7.7\%) in the School of Environmental Technology as the department with the highest number of students who participated in the study. Departments with the lowest number of students ( 2 or $0.5 \%$ ) included Physics, Applied Geology and Information Science.

Table 3. Gender of Respondents

\begin{tabular}{|l|l|l|}
\hline Gender & Frequency & Percentage (\%) \\
\hline Male & 239 & 63.4 \\
\hline Female & 138 & 36.6 \\
\hline TOTAL & $\mathbf{3 7 7}$ & $\mathbf{1 0 0 . 0}$ \\
\hline
\end{tabular}

Out of the population used for the study, 239 (63.4\%) of the respondents were males and $138(36.6 \%)$ were females (see table 3). 341 (90.5\%) were undergraduates and $36(9.5 \%)$ of them were postgraduate students. Of 36 postgraduate students that participated in the study, table 4 shows that an equal number of students undertake Master's and PhD programmes while 4 respondents were students undertaking postgraduate diploma programmes in the University.

Table 4. Postgraduate Level of Respondents

\begin{tabular}{|l|l|l|}
\hline Postgraduate Level & Frequency & Percentage (\%) \\
\hline PGD & 4 & 1.1 \\
\hline MTECH & 16 & 4.2 \\
\hline PhD & 16 & 4.2 \\
\hline TOTAL & $\mathbf{3 6}$ & $\mathbf{9 . 5}$ \\
\hline
\end{tabular}


Table 5. Undergraduate Level of Respondents

\begin{tabular}{|l|l|l|}
\hline Undergraduate Level & Frequency & Percentage (\%) \\
\hline 100 & 79 & 21 \\
\hline 200 & 133 & 35.3 \\
\hline 300 & 72 & 19.1 \\
\hline 400 & 43 & 11.4 \\
\hline 500 & 14 & 3.7 \\
\hline TOTAL & $\mathbf{3 4 1}$ & $\mathbf{9 0 . 5}$ \\
\hline
\end{tabular}

Table 5 shows the number of undergraduate students that participated in the study. Students in their second year ranked the highest with $133(35.3 \%)$ respondents who participated in the study. Students in 100 level or in their first year in the University ranked second ( 79 or $21 \%$ ) among respondents who participated in the study. In descending order, the table also showed undergraduate students in 300 level (72 or 19.1\%), 400 level (43 or $11.4 \%)$ and 500 level (14 or 3.7\%) as participants in the study.

Table 6. Age Group of Respondents

\begin{tabular}{|l|l|l|}
\hline Age Group & Frequency & Percentage (\%) \\
\hline $14-19$ & 174 & 46.2 \\
\hline $20-25$ & 136 & 36.1 \\
\hline $26-31$ & 40 & 10.6 \\
\hline $32-37$ & 15 & 4.0 \\
\hline 38 and above & 12 & 3.2 \\
\hline TOTAL & $\mathbf{3 7 7}$ & $\mathbf{1 0 0 . 0}$ \\
\hline
\end{tabular}

The age group of respondents are highlighted in table 6 . Majority of the respondents $(174$ or $46.2 \%)$ were between ages 14 and 19. This is closely followed by respondents with ages 20 to 25 (136 or $36.1 \%$ ). University students in mid or late twenties (40 or 10.6\%) were captured between ages 26 and 31 and those in their early thirties were $15(4.0 \%)$. The least number of respondents (12 or $3.2 \%$ ) who participated in the study were above 38 years old. Findings indicated that most university students are youths or in the prime of their lives.

Table 7. Health Information Needs of Respondents

\begin{tabular}{|l|l|l|l|l|l|l|}
\hline What kind of information do you seek? & \multicolumn{2}{l|}{ Agree } & \multicolumn{2}{l|}{ Disagree } & \multicolumn{2}{l|}{ Total } \\
\cline { 2 - 7 } & Freq & $\%$ & Freq & $\%$ & Freq & $\%$ \\
\hline Physical fitness/exercise & 239 & 63.4 & 138 & 36.6 & 377 & 100.0 \\
\hline Nutrition/Diet & 130 & 34.5 & 247 & 65.5 & 377 & 100.0 \\
\hline mental heath & 214 & 56.8 & 163 & 43.2 & 377 & 100.0 \\
\hline Sexual/reproduction heath & 199 & 52.8 & 178 & 47.2 & 377 & 100.0 \\
\hline Fever & 179 & 47.5 & 198 & 52.5 & 377 & 100.0 \\
\hline Cold/flu & 239 & 63.4 & 138 & 36.6 & 377 & 100.0 \\
\hline STDs & 170 & 45.1 & 207 & 54.9 & 377 & 100.0 \\
\hline HIV/AIDS & 195 & 51.7 & 182 & 48.3 & 377 & 100.0 \\
\hline Menstrual pain & 60 & 15.9 & 317 & 84.1 & 377 & 100.0 \\
\hline
\end{tabular}

Research Question 1: What are the health information needs of university students?

In table 7, the information needs of respondents are highlighted. Respondents' predominant needs included physical fitness/exercise and cold/flu (239 or 63.4\%). Information on mental health (214 or 56.8\%) ranked next on the rung of health information needs sought by university students. $199(52.8 \%)$ respondents agreed that they sought information on sexual or reproductive health. 195 (51.7\%) respondents specifically sought information on HIV/AIDS and $130(34.5 \%)$ consented to seeking information on nutrition and diet. The table showed menstrual pain $(60$ or $15.9 \%)$ as the least information need and consequently recorded the highest number of respondents (317 or $84.1 \%$ ) who disagreed to seeking information in that regard. 
Table 8. Sources of Health Information Used by Respondents

\begin{tabular}{|l|l|l|l|l|l|l|}
\hline Source of health information & \multicolumn{2}{l|}{ Agree } & \multicolumn{2}{l|}{ Disagree } & \multicolumn{2}{l|}{ Total } \\
\cline { 2 - 7 } & Freq & $\%$ & Freq & $\%$ & Freq & $\%$ \\
\hline Newspaper & 283 & 75.1 & 94 & 24.9 & 377 & 100.0 \\
\hline Internet & 170 & 45.1 & 207 & 54.9 & 377 & 100.0 \\
\hline Medical books & 175 & 46.4 & 202 & 53.6 & 377 & 100.0 \\
\hline Social medial platforms (e.g. WhatsApp, Facebook) & 199 & 52.8 & 178 & 47.2 & 377 & 100.0 \\
\hline Journal articles & 277 & 73.5 & 100 & 26.5 & 377 & 100.0 \\
\hline Family and friends & 115 & 30.5 & 262 & 69.5 & 377 & 100.0 \\
\hline Physical/other types of medical personnel & 217 & 57.6 & 160 & 42.4 & 377 & 100.0 \\
\hline Television & 234 & 62.1 & 143 & 37.9 & 377 & 100.0 \\
\hline Radio & 248 & 65.8 & 129 & 34.2 & 377 & 100.0 \\
\hline
\end{tabular}

Research Question 2: What information resources do university students exploit to meet their health information needs?

Table 8 shows the information resources exploited by university students when they seek health information. Findings identified the newspaper (283 or $75.1 \%$ ) as respondents' commonest source of health information. 277 (73.5\%) respondents consult journal articles for health information. This may be attributed to the fact they are within the university community and undertake academic activities on a regular basis. The radio (248 or $65.8 \%)$ and television ( 234 or $62.1 \%$ ) are ranked next among information resources consulted by university students when seeking health information. The table shows that $217(59.6 \%)$ respondents consult physicians or other types of medical personnel. Some respondents patronise social media (199 or 52.8\%), books on Medicine (175 or 46.4\%), and the internet (170 or $45.1 \%$ ). Family and friends (115 or $30.1 \%$ ) are also considered by some respondents as viable sources of health information.

Table 9. Respondents' Intentions for Seeking Health Information

\begin{tabular}{|l|l|l|l|l|l|l|}
\hline Respondents' intentions for seeking health & \multicolumn{2}{l|}{ Agree } & \multicolumn{2}{l|}{ Disagree } & \multicolumn{2}{l|}{ Total } \\
\cline { 2 - 7 } information & Freq. & $\mathbf{\%}$ & Freq. & $\%$ & Freq. & $\%$ \\
\hline I buy drugs from patent medicine store & 147 & 39.0 & 230 & 61.0 & 377 & 100.0 \\
\hline I just want to know so I don't do anything & 288 & 76.4 & 89 & 23.6 & 377 & 100.0 \\
\hline I go to the hospital for treatment & 199 & 52.8 & 178 & 47.2 & 377 & 100.0 \\
\hline I visit a herbalist/traditional healer for treatment & 190 & 50.4 & 187 & 49.6 & 377 & 100.0 \\
\hline I seek advice from friends & 235 & 62.3 & 142 & 37.7 & 377 & 100.0 \\
\hline I seek help from family members & 219 & 58.1 & 158 & 41.9 & 377 & 100.0 \\
\hline
\end{tabular}

Research Question 3: What are students' intentions for seeking health information among university students? The result of this research question was indicated through the use of frequency and percentages revealing students' intentions for seeking health information. In table 9 , the majority of the respondents $(288$ or $76.4 \%)$ desire to have health information without acting on it. While the least number of respondents ( 89 or $23.6 \%$ ) disagree. In their opinion, health information sought should be acted upon. 235 (62.3\%) respondents seek advice from friends after seeking health information. 219 (58.1\%) seek help from family members and 147 (39.0\%) respondents purchase drugs from patent medicine stores. 199 (52.8\%) are inclined to seeking treatment in hospitals after seeking health information while $178(47.2 \%)$ oppose the notion of doing so. Interestingly, there is a thin margin between those who seek treatment from herbalists and traditional healers (190 or 50.4\%) and those who reject the idea (187 or 49.6\%). This finding may, however, imply that some students advocate the use of herbs or traditional medicine for treatment after seeking information about their health status.

Table 10. Respondents' Choice of Topics When They Visit the Library

\begin{tabular}{|l|l|l|l|l|l|l|}
\hline \multirow{2}{*}{ Topics consulted in the University Library } & Agree & \multicolumn{2}{l|}{ Disagree } & \multicolumn{2}{l|}{ Total } \\
\cline { 2 - 7 } & Freq. & $\%$ & Freq. & $\%$ & Freq & $\%$ \\
\hline Health & 203 & 53.8 & 174 & 46.2 & 377 & 100.0 \\
\hline Entertainment & 229 & 60.7 & 148 & 39.3 & 377 & 100.0 \\
\hline Education & 171 & 45.4 & 206 & 54.6 & 377 & 100.0 \\
\hline Fashion news & 213 & 56.5 & 164 & 43.5 & 377 & 100.0 \\
\hline Politics/current Affairs & 248 & 65.8 & 129 & 34.2 & 377 & 100.0 \\
\hline Sports & 185 & 49.1 & 192 & 50.9 & 377 & 100.0 \\
\hline
\end{tabular}

In table 10, respondents' most preferred choice on topics consulted when they visit the library was politics or current affairs (248 or 65.8\%). 229 (60.7\%) respondents agree to seeking information on entertainment while 213 $(56.5 \%)$ respondents seek information on fashion news. Health information (203 or 53.8\%) ranked fourth among topics sought by respondents during library visits. The table also showed that respondents are not very keen on 
seeking information on sports (185 or $49.1 \%$ ) and education (171 or $45.4 \%$ ) which came least on topics sought after by respondents.

Table 11. Respondents' Reasons for Non-Use of Library Resources

\begin{tabular}{|l|l|l|l|l|l|l|}
\hline Reasons for non-use of library resources & Agree & \multicolumn{2}{l|}{ Disagree } & \multicolumn{2}{l|}{ Total } \\
\cline { 2 - 7 } & Freq. & $\%$ & Freq. & $\%$ & Freq. & $\%$ \\
\hline Information resources are outdated & 167 & 44.3 & 210 & 55.7 & 377 & 100.0 \\
\hline Poor internet services & 207 & 54.9 & 170 & 45.1 & 377 & 100.0 \\
\hline Insufficient information materials to read & 258 & 68.7 & 118 & 31.3 & 377 & 100.0 \\
\hline I am too busy & 159 & 42.2 & 218 & 57.8 & 377 & 100.0 \\
\hline I find it difficult to access library & 187 & 49.6 & 190 & 50.4 & 377 & 100.0 \\
\hline
\end{tabular}

Table 12. Problems of Access to Health Information in the Library

\begin{tabular}{|l|l|l|l|l|l|l|}
\hline Problems of accessing health information & \multicolumn{2}{l|}{ Agree } & \multicolumn{2}{l|}{ Disagree } & \multicolumn{2}{l|}{ Total } \\
\cline { 2 - 7 } & Freq. & $\mathbf{\%}$ & Freq. & $\%$ & Freq. & \% \\
\hline Obsolete information materials & 237 & 62.9 & 140 & 37.1 & 377 & 100.0 \\
\hline Inadequate information resources & 174 & 46.2 & 203 & 53.8 & 377 & 100.0 \\
\hline Uncooperative behavior of library personnel & 240 & 63.7 & 137 & 36.3 & 377 & 100.0 \\
\hline Poor internet connection & 227 & 60.2 & 150 & 39.8 & 377 & 100.0 \\
\hline $\begin{array}{l}\text { I don't know the library has information materials on health } \\
\text { information }\end{array}$ & 98 & 26.0 & 279 & 74.0 & 377 & 100.0 \\
\hline
\end{tabular}

Research Question 4: What problems do university students encounter when seeking health information in the library?

In table 12, problems faced by respondents when seeking health information in the library were delineated. The uncooperative attitude of library personnel (240 or $63.7 \%$ ) was identified as a major hindrance in accessing health information in the library. This was closely followed by the existence of obsolete materials ( 237 or $62.9 \%)$ in the library collection. The table also reflects poor internet connectivity $(227$ or $60.2 \%$ ) as a problem faced by respondents. Though 279 (74.8\%) respondents claimed awareness of the existence of health information materials in the library, 174(46.2\%) of them believe that these resources are inadequate and thus, feel discouraged to use health information resources in the library. This lends credence to respondents' reasons for not utilising health information materials in the library as is shown in table 11. Insufficient information materials (258 or $68.7 \%$ ), poor internet connectivity (207 or 54.9\%) and outdated information resources (167 or $44.3 \%$ ) were highlighted as respondents' reasons for poor patronage of the library. Some respondents claimed difficulty in accessing library materials (187 or $49.6 \%$ ) while others ( 159 or $42.2 \%$ ) mentioned being too busy to visit the library.

Table 13. Factors Inhibiting Access to Health Information Outside the Library

\begin{tabular}{|c|c|c|c|c|c|c|}
\hline \multirow[t]{2}{*}{ Factors inhibiting access to health information } & \multicolumn{2}{|c|}{ Agree } & \multicolumn{2}{|c|}{ Disagree } & \multicolumn{2}{|c|}{ Total } \\
\hline & Freq. & $\%$ & Freq. & $\%$ & Freq. & $\%$ \\
\hline $\begin{array}{l}\text { lack of knowledge on how to get appropriate information outside } \\
\text { the university library }\end{array}$ & 263 & 69.8 & 114 & 30.2 & 377 & 100.0 \\
\hline High financial cost of access to health information & 318 & 84.4 & 59 & 15.6 & 377 & 100.0 \\
\hline Fear of disclosing health problems to others & 121 & 32.1 & 256 & 67.9 & 377 & 100.0 \\
\hline Difficulty in determining the correctness & 252 & 66.8 & 125 & 33.2 & 377 & 100.0 \\
\hline $\begin{array}{l}\text { I don't have any challenges because I can find a solution to any } \\
\text { health problem by myself }\end{array}$ & 239 & 63.4 & 138 & 36.6 & 377 & 100.0 \\
\hline
\end{tabular}

Research Question 5: What are the factors that inhibit access to health information among university students outside the library?

Table 13 highlights the factors inhibiting access to health information among university students. Majority of the respondents (318 or $84.4 \%$ ) indicated that accessing health information comes at a high cost and $263(69.8 \%)$ of them lack the knowledge on how to obtain health information. Respondents' difficulty in determining the authenticity of health information (252 or 66.8\%) and fear of disclosing health problems to others (121 or 32.1\%) were also identified as factors that hinder access to health information among the students. Interestingly, 239 (63.4\%) declared no challenge in seeking health information because they can find a solution to such problems themselves.

\section{Discussion}

From the study, findings revealed the health information needs of university students who participated in the study. Respondents' predominant need bordered on physical fitness/exercise and cold/flu (239 or 63.4\%). This result is 
in congruence with the findings of Onwe \& Okocha (2019) who investigated the health information-seeking behaviour among Nigerian university students. In their report, respondents' most sought health information was on how to keep fit physically (88.2\%). From the findings in this study, information on mental health (214 or 56.8\%) ranked next on students' most sought health information. Sexual or reproductive health (199 or 52.8\%), HIV/AIDS (195 or $51.7 \%$ ), nutrition and diet (130 or 34.5\%) and menstrual pain (60 or 15.9\%) were highlighted as health information needs of university students. The study identified respondents' preferred health information resources. The newspaper was indicated as respondents' commonest source of information (283 or $75.1 \%$ ). This result contravenes the submissions of Asibey et al. (2017) and Dutta-Bergman (2004) that the internet is mostly used by youths to meet health information needs. Rather, the internet according to the findings in the study, was considered one of the least resources consulted by respondents in their search for health information (170 or $45.1 \%$ ). Journal articles $(277$ or $73.5 \%$ ), radio (248 or $65.8 \%$ ), television (234 or $62.1 \%$ ) were identified as health information resources consulted by respondents. Students' patronage of physicians and other types of medical personnel (217 or $59.6 \%$ ), medical literature (175 or $46.4 \%$ ) as well as family and friends (115 or $30.1 \%$ ) were also identified in the study.

Respondents' intentions for seeking health information were outlined in the study. Majority of the respondents ( 288 or $76 \%$ ) simply wanted information on their health status and planned on taking no action on it. Seeking advice from people such as friends (235 or 62.3\%) and help from family members (219 or 58.1\%) were included among the intentions of respondents when they obtain health information. Some other students patronise hospitals for treatment (199 or 52.8\%), herbalists or traditional healers (190 or 50.4\%) and patent stores (147 or $39.0 \%$ ) after obtaining health information. These findings support the reports in some studies which affirm youths' reliance on family and friends more than medical personnel when they attempt to address health-related issues (Esmaeilzadeh et al. 2018; Okoniewski et al. 2015; Ettel et al. 2012).

The library as an information institution serves as a focal point for the processing, storage and dissemination of relevant information and should promote access to health information among university students. However, findings from the study revealed problems students encounter when seeking health information in the library. On a general note, respondents indicated their reasons for not patronising library resources. Insufficient information resources (258 or $68.7 \%$ ), poor internet connectivity (207 or 54.9\%), difficulty in accessing library materials (187 or $49.6 \%$ ) and existing outdated information resources (167 or $44.3 \%$ ) were highlighted as reasons for poor patronage of the university library. Some respondents (159 or $42.2 \%$ ) mentioned being too busy to visit the library. In the quest for health information in the library, the uncooperative attitude of library personnel $(240$ or $63.7 \%)$ towards respondents was identified as a major hindrance to seeking health information in the library. Esmaeilzadeh et al. (2018) in their study, identified this deficiency and suggested the active involvement of the librarian in the efficient and effective provision of health information among youths in the present age. Other challenges faced by respondents depicted in the findings include obsolete health information resources (237 or $62.9 \%$ ) and poor internet connectivity (227 or $60.2 \%$ ) in accessing health information on-line. The result affirms the assertions of Onwe \& Okocha (2019), Okoniewski et al. (2015), and Duhon and Jameson (2013) which identified libraries' poor promotion of health education as a hindrance to the provision of health information among youths. The library's potential to provide adequate health information to the teeming population of youths is indeed yet to be exploited.

The study also revealed factors that inhibit students' access to health information outside the university library. The high cost of accessing health information (318 or $84.4 \%$ ) discourages respondents from obtaining the health information they need. Lack of knowledge on how to obtain health information (263 or 69.8\%) and difficulty in determining the authenticity or correctness of the health information received (252 or $66.8 \%$ ) were identified as inhibitors to students' access to health information. Also, the table revealed a total of 121 (32.1\%) respondents who indicated their fear of disclosing their health issues to others. The result is concordant with the reports in some studies that divulge poor accessibility to health information, fear of receiving false health information and of disclosing personal health matters to people as challenges beleaguering youths in their search for health information (Ettel et al. 2012 \& Boltena et al. 2012).

\section{Conclusion}

The study revealed the importance of health information even among university students and the significant impact it may have on their overall development. However, some of them do not enjoy the effective use of health information. This majorly owes to the challenge of insufficient knowledge of where and how to access authentic health information. The library which should serve as a health information provider lacks adequate resources on health management. Such a condition can discourage university students from utilising health information resources and other materials that may be relevant to their studies and consequently hamper academic activities among university students. More provision of health information resources is therefore encouraged to increase students' use of information resources in the library. Also, library personnel should be trained and re-trained in the delivery of library services in order to enhance effective library service delivery and improve clientele's perception of the library and its operations. 


\section{Recommendations}

Based on the findings of the study, the following recommendations are made:

- Adequate provision of up-to-date health information resources should be made by the university administration in the university library for students' use.

- Regular training and re-training programmes for library personnel on professional ethics should be conducted. It is believed that proper orientation on workers' schedule of duty especially towards library clienteles will improve staff-student relationship positively and ultimately attract students to use library resources.

- There should be synergy between the university administration and relevant health bodies in promoting health activities within the university. The university library should be made to play a participatory role in the organisation of lectures and other sensitisation programmes relating to health management. During such programmes, libraries may provide guidance in the search and effective use of health information among university students.

\section{References}

Ajiboye, J. O., \& Tella, A. (2007), "University undergraduate students' information seeking behaviour: implications for quality in higher education in Africa", The Turkish Online Journal of Educational Technology 6(1), 40-52.

Andualem, M., Kebede, G. \& Kumie A. (2013), "Information needs and seeking behaviour among health professionals working at hospital and health centres in Bahir Dar, Ethiopia" BMC Health Services Research 2013, 13, 1-9. http://www.biomedcentral.com/1472-6963/13/534

Asibey, B., Agyemang, S. \& Dankwah, A. (2017), "The internet use for health information seeking among Ghanaian university students: A cross-sectional study", International Journal of Telemedicine and Applications, 1-9.

Boltena, A.T., Khan, F.A., Asamoah, B.O. \& Agardh, A. (2012), "Barriers faced by Ugandan university students in seeking medical care and sexual health counselling: a cross sectional study", BMC Public Health 12, 1-8. http://www.biomedcentral.com/1471-2458/12/986

Duhon, L., \& Jameson, J. (2013), "Health information outreach: A survey of U.S. academic libraries, highlighting a Midwestern university's experience", Health Information and Libraries Journal 30, 121-137.

Dutta-Bergman, M. (2004), "Primary sources of health information: comparisons in the domain of health attitudes, health cognitions, and health behaviors", Department of Communication, Purdue University, Indiana.

Esmaeilzadeh, S., Ashrafi-rizi, H., Shahrzadi, L. \& Mostafavi, F. (2018), "A survey on adolescent health information seeking behavior related to high-risk behaviors in a selected educational district in Isfahan", PLoSONE 13(11) https://doi.org/10.1371/journal.pone.0206647

Ettel, G. III, Nathanson, I., Ettel, D., Wilson, C. \& Meola, P. (2012), "How do adolescents access health information? And do they ask their physicians?", The Permanente Journal 16(1) 35-38.

Krejcie, R.V. \& Morgan, D.W. (1970), "Determining sample size for research activities", Educational and Psychological Measurement 30, 607-610.

Ma, J., Stahl, L. \& Knotts, E. (2018), "Emerging roles of health information professionals for library and information science curriculum development: a scoping review", Journal of The Medical Library Association 106(4) 432-444. www.ncbi.nlm.nih.gov

Nwezeh, M. (2008), "Health information needs of first-year students in Nigerian universities: a case study of Obafemi Awolowo University, Ile-Ife", Journal of Hospital Librarianship 8, 201 - 210.

Obasola, O. \& Agunbiade, O. (2016), "Online health information seeking pattern among undergraduates in a Nigerian university”, SAGE Open, 6 1, 1-9.

Okoniewski, A.E., Lee, Y. J., Rodriguez, M., Schnall, R. \& Low, A.F.H. (2015), "Health information seeking behaviors of ethnically diverse adolescents", J Immigr Minor Health 16(4) 652-660.

Onwe, C. \& Okocha, F. (2019), "Health information seeking behaviour of university students in Nigeria", Library Philosophy and Practice https://digitalcommons.unl.edu/libphilprac/2498 (February 9, 2020)

Percheski, C. \& Hargittai, E. (2011), "Health information seeking in the digital age", Journal of American College Health 59(5) 379-386.

Shi, Y. \& Luo, L. (2019), “Chinese college students' health information seeking behaviour implications for academic libraries", Journal of Academic Librarianship, 45(1), 69-74

Tiamiyu, M. (2003), "Information and communication technology for social development: issues, options and strategies”, in Soola, E. O. (Ed.). Communication for Development Purposes. Ibadan: Kraft Books Ltd.

\section{Declaration of Interests}

The authors declare that they have no conflict of interests. 


\section{Funding}

This research received no specific grant from any funding agency in the public, commercial or not-for-profit sectors. The authors were solely responsible for the funding of this research.

\section{Authors' contributions}

Both authors contributed to the development of the study. Omonigho Angela Israel was involved with writing the initial draft of the manuscript. Olufemi Olusegun Samuel was involved in analysing the data used for the research. Both authors read and approved the final draft of the manuscript.

\section{About the Authors}

Omonigho Angela Israel is a Senior Librarian in the Cataloguing and Classification Department, Federal University of Technology, Akure (FUTA), Ondo State, Nigeria. Before this role, she was Librarian and later Head of Acquisitions Department at the Ajayi Crowther University, Oyo State, Nigeria (2008-2011). She was also Head of Acquisitions Department at FUTA (2012-2014). She has worked as a cataloguer in the Cataloguing and Classification Department, FUTA since 2015. Omonigho holds a Master of Library and Information Science (MLS) and a Bachelor of Library and Information Science (BLS) from the University of Ibadan, Nigeria.

Olufemi Olusegun Samuel is a Higher Library Officer and has worked in the E-Resources Department, Federal University of Technology, Akure, (FUTA), Ondo State, Nigeria. Presently, Olufemi works at The School of Postgraduate Studies Library, Federal University of Technology Akure and liaises between the Dean, School of Postgraduate Studies and the University Librarian. Olufemi holds a Master of Library and Information Science (MLS) and a Bachelor of Library and Information Science (BLS) from Delta State University, Abraka, Delta State, Nigeria.

\section{Appendices Appendix A: \\ QUESTIONNAIRE ON HEALTH INFORMATION SEEKING BEHAVIOUR AMONG STUDENTS IN THE FEDERAL UNIVERSITY OF TECHNOLOGY, AKURE, ONDO STATE, NIGERIA.}

\section{Dear Respondent,}

I am soliciting your kind assistance to complete the questionnaire below. It is designed to find out the health information-seeking behaviour among students of the Federal University of Technology, Akure.

Information provided will be treated with the utmost confidence and used strictly for this research.

Thank you.

Instruction: Please answer the following questions by either a tick in the appropriate box or by writing in the space provided. Thank you.

A. General Information

1. Faculty:

2. Department:

3. Undergraduate Level:

4. Gender: (a) Male ( ) (b) Female ( )

5. Age Group: (a) 14-19 ( ) (b) 20-26 ( ) (c) 27-31 ( ) (d) 31-35 ( ) (e) 36 and above ( )

B. Information Needs

C. Information Seeking Behaviour

6. What kind of health information do you seek?

\begin{tabular}{|l|l|l|}
\hline Type of information sought & Agree & Disagree \\
\hline Physical fitness/exercise & & \\
\hline Nutrition/Diet & & \\
\hline Mental health & & \\
\hline Sexual/reproduction heath & & \\
\hline Fever & & \\
\hline Cold/flu & & \\
\hline STDs & & \\
\hline HIV/AIDS & & \\
\hline Menstrual pain & & \\
\hline
\end{tabular}


7. What kind of information sources do you consult to get health information?

\begin{tabular}{|l|l|l|}
\hline Information Source & Agree & Disagree \\
\hline Newspaper & & \\
\hline Internet & & \\
\hline Medical books & & \\
\hline Social medial platforms (e.g. WhatsApp, Facebook) & & \\
\hline Journal articles & & \\
\hline Family and friends & & \\
\hline Physical/other types of medical personnel & & \\
\hline Television & & \\
\hline Radio & & \\
\hline
\end{tabular}

8. For which of these topics do you visit the university library?

\begin{tabular}{|l|l|l|}
\hline Topics & Agree & Disagree \\
\hline Health & & \\
\hline Entertainment & & \\
\hline Education & & \\
\hline Fashion news & & \\
\hline Politics/Current Affairs & & \\
\hline Sports & & \\
\hline
\end{tabular}

9. What are your reasons for not consulting the university library for health information?

\begin{tabular}{|l|l|l|}
\hline $\begin{array}{l}\text { Reasons for not consulting Health Information in the } \\
\text { Library }\end{array}$ & Agree & Disagree \\
\hline Information resources are outdated & & \\
\hline Poor internet services & & \\
\hline Insufficient information materials to read & & \\
\hline I am too busy & & \\
\hline I find it difficult to access the library & \\
\hline
\end{tabular}

10. Which of these problems do you encounter when trying to get health information in the university library?

\begin{tabular}{|l|l|l|}
\hline $\begin{array}{l}\text { Problems Encountered when Obtaining Health } \\
\text { Information in the Library }\end{array}$ & Agree & Disagree \\
\hline obsolete information material & & \\
\hline Inadequate information resources & & \\
\hline Uncooperative behaviour of library personnel & & \\
\hline Poor internet connection & & \\
\hline $\begin{array}{l}\text { I don't know the library has information materials on health } \\
\text { information }\end{array}$ & & \\
\hline
\end{tabular}

11. What challenges do you face in getting health information outside the university library?

\begin{tabular}{|l|l|l|}
\hline $\begin{array}{l}\text { Challenges in Obtaining Health Information Outside the } \\
\text { Library }\end{array}$ & Agree & Disagree \\
\hline $\begin{array}{l}\text { Lack of knowledge on how to get appropriate information } \\
\text { outside the university library? }\end{array}$ & & \\
\hline The high financial cost of access to health information & & \\
\hline Fear of disclosing health problems to others & & \\
\hline Difficulty in determining the correctness & & \\
\hline $\begin{array}{l}\text { I don't have any challenges because I can find a solution to } \\
\text { any health problem by myself }\end{array}$ & & \\
\hline
\end{tabular}


12. What do you do with the health information you obtain?

\begin{tabular}{|l|l|l|}
\hline Use of health information obtained & Agree & Disagree \\
\hline I buy drugs from patent medicine store & & \\
\hline I just want to know so I don't do anything & & \\
\hline I go to the hospital for treatment & & \\
\hline I visit a herbalist/traditional healer for treatment & & \\
\hline I seek advice from friends & & \\
\hline I seek help from family members & & \\
\hline
\end{tabular}

\title{
Appendix B:
}

EDUCATIONAL AND PSYCHOLOGICAL MEASUREMENT

1970, 30, 607-610.

\section{DETERMINING SAMPLE SIZE FOR RESEARCH ACTIVITIES}

\author{
ROBERT V. KREJCIE \\ University of Minnesota, Duluth
}

DARYLE W. MORGAN

Texas A. \& M. University

The ever increasing demand for research has created a need for an efficient method of determining the sample size needed to be representative of a given population. In the article "Small Sample Techniques," the research division of the National Education Association has published a formula for determining sample size. Regrettably a table has not been available for ready, easy reference which could have been constructed using the following formula.

$$
s=X^{2} N P(1-P) \div d^{2}(N-1)+X^{2} P(1-P)
$$

$s=$ required sample size

$X^{2}=$ the table value of chi-square for 1 degree of freedom at the desired confidence level (3.841).

$N=$ the population size.

$P=$ the population proportion (assumed to be .50 since this would provide the maximum sample size).

$d=$ the degree of accuracy expressed as a proportion (.05).

No calculations are needed to use Table 1. For example, one may wish to know the sample size required to be representative of the opinions of 9000 high school teachers relative to merit pay increases. To obtain the required sample size enter Table 1 at $\mathrm{N}=9000$. The sample size representative of the teachers in this example is 368 . Table 1 is applicable to any defined population.

The relationship between sample size and total population is illustrated in Figure 1. It should be noted that as the population increases the sample size increases at a diminishing rate and remains relatively constant at slightly more than 380 cases.

\section{REFERENCE}

Small-Sample Techniques. The NEA Research Bulletin, Vol. 38 (December, 1960), p. 99. 
TABLE 1

Table for Determining Sample Size from a Given Population

\begin{tabular}{|c|c|c|c|c|c|}
\hline$N$ & $S$ & $N$ & $S$ & $N$ & $S$ \\
\hline 10 & 10 & 220 & 140 & 1200 & 291 \\
\hline 15 & 14 & 230 & 144 & 1300 & 297 \\
\hline 20 & 19 & 240 & 148 & 1400 & 302 \\
\hline 25 & 24 & 250 & 152 & 1500 & 306 \\
\hline 30 & 28 & 260 & 155 & 1600 & 310 \\
\hline 35 & 32 & 270 & 159 & 1700 & 313 \\
\hline 40 & 36 & 280 & 162 & 1800 & 317 \\
\hline 45 & 40 & 290 & 165 & 1900 & 320 \\
\hline 50 & 44 & 300 & 169 & 2000 & 322 \\
\hline 55 & 48 & 320 & 175 & 2200 & 327 \\
\hline 60 & 52 & 340 & 181 & 2400 & 331 \\
\hline 65 & 56 & 360 & 186 & 2600 & 335 \\
\hline 70 & 59 & 380 & 191 & 2800 & 338 \\
\hline 75 & 63 & 400 & 196 & 3000 & 341 \\
\hline 80 & 66 & 420 & 201 & 3500 & 346 \\
\hline 85 & 70 & 440 & 205 & 4000 & 351 \\
\hline 90 & 73 & 460 & 210 & 4500 & 354 \\
\hline 95 & 76 & 480 & 214 & 5000 & 357 \\
\hline 100 & 80 & 500 & 217 & 6000 & 361 \\
\hline 110 & 86 & 550 & 226 & 7000 & 364 \\
\hline 120 & 92 & 600 & 234 & 8000 & 367 \\
\hline 130 & 97 & 650 & 242 & 9000 & 368 \\
\hline 140 & 103 & 700 & 248 & 10000 & 370 \\
\hline 150 & 108 & 750 & 254 & 15000 & 375 \\
\hline 160 & 113 & 800 & 260 & 20000 & 377 \\
\hline 170 & 118 & 850 & 265 & 30000 & 379 \\
\hline 180 & 123 & 900 & 269 & 40000 & 380 \\
\hline 190 & 127 & 950 & 274 & 50000 & 381 \\
\hline 200 & 132 & 1000 & 278 & 75000 & 382 \\
\hline 210 & 136 & 1100 & 285 & 1000000 & 384 \\
\hline
\end{tabular}

Note. $-N$ is population size.

$S$ is sample size.

Retrieved from https://journals.sagepub.com/doi/abs/10.1177/001316447003000308?journalCode=epma 